\title{
Contested meanings of inclusiveness, accountability and transparency in trade policymaking
}

\author{
Jeremy Malcolm \\ Electronic Frontier Foundation, San Francisco, United States of America
}

Published on 30 Dec 2017 | DOI: 10.14763/2017.4.772

\begin{abstract}
Inclusiveness, accountability and transparency carry different meanings in the context of different public policy processes, and for different stakeholder groups engaged in those processes. In particular, civil society has had a substantial role in conceptualising these meanings in internet governance policy spaces, but a much reduced rule in their explication in trade policymaking. It will be argued that greater support for trade policymaking could arise from a project to reconcile civil society's expectations of the inclusiveness, accountability and transparency of trade negotiations with the political realities of the trade negotiator, while at the same time enhancing negotiators' appreciation of the metrics that civil society stakeholders will use in assessing trade negotiations, especially those that relate to the internet.
\end{abstract}

Keywords: Trade, Internet governance, Civil society, Transparency, Multi-stakeholderism

\section{Article information}

Received: 12 Jul 2017 Reviewed: 18 Oct 2017 Published: 30 Dec 2017

Licence: Creative Commons Attribution 3.0 Germany

Funding: The cost of a flight to Paris for presentation of this paper was paid by the Institut des

Amériques.

Competing interests: The author has declared that no competing interests exist that have influenced

the text.

URL:

http://policyreview.info/articles/analysis/contested-meanings-inclusiveness-accountability-and-transp arency-trade

Citation: Malcolm, J. (2017). Contested meanings of inclusiveness, accountability and transparency in trade policymaking. Internet Policy Review, 6(4). https://doi.org/10.14763/2017.4.772

Recent plurilateral trade negotiations such as the Trans-Pacific Partnership (TPP), the Trade in Services Agreement (TISA), the Anti-Counterfeiting Trade Agreement (ACTA), the Regional Comprehensive Economic Partnership (RCEP), and the reopened North American Free Trade Agreement (NAFTA), are addressing a range of digital governance issues that have never before been the subject of trade agreements. A number of these issues, such as net neutrality, rules about internet domain names, encryption standards, and software source code, have previously been addressed through more open mechanisms and institutions of governance associated with the internet governance regime. 
As a result, stakeholders associated with that regime, such as members of the internet technical community and internet activist groups, have come to expect certain standards of transparency and broad public consultation in policymaking on internet-related issues. This is not unjustified, as these expectations stem from the same ideals of democratic governance that underpin other transnational political movements (Mueller, 2010, p.1). These stakeholders have responded to the inclusion of such issues in closed and opaque trade negotiations with fierce public opposition, resulting in the ultimate failure of some of these agreements, such as the TPP from which the United States withdrew in 2016, and ACTA which the European Union declined to endorse in 2012.

One example of such a provision that has migrated from internet governance into trade is a rule that appeared in the final text of the TPP in Article 14.14, requiring countries to adopt measures for the control of spam, or unsolicited electronic mail. Similar provisions have been proposed for TISA, RCEP, and NAFTA. Until the appearance of this provision in these trade texts, spam control had hitherto only been addressed at an international level in soft internet governance fora such as the Internet Governance Forum (IGF) and the Coalition Against Unsolicited Commercial Email (CAUCE), and in technical standards development bodies such as the Internet Engineering Task Force (IETF).

If trade agreements are to be used to address such internet-related public policy issues, public support for this would appear to be contingent upon improving the inclusiveness, accountability, and transparency of the negotiations, so that civil society does not feel that it has been systematically excluded, and also so that the substantive content of the agreements can benefit from review by a broader range of affected stakeholders.

There is much research on appropriate definitions and measures of inclusiveness, accountability and transparency in various contexts, including multi-stakeholder governance networks (Malcolm, 2008, pp. 260-282), however reviewing such literature is not an objective of this short paper. Suffice it to say for present purposes that inclusiveness is a measure of the extent to which a diversity of interests of the involved stakeholders informs and deepens policy discussions and policy development processes (Belli, 2015). Accountability includes the measures that a policy process incorporates to demonstrate its input legitimacy to stakeholders; that is, measures that increase the perception of those stakeholders that its outputs are justified (Mena and Palazzo, 2012). Depending on the process, these may include processes for the nomination and election of representatives, for procedural fairness in decision-making, for internal or external review or appeal, and so on. Finally the closely associated concept of the transparency of a policy process can be defined as public access to its records (which may include meeting minutes, reports, mailing list discussions, and financial documents), and also to its meetings (Piotrowski and Borry, 2010).

Rather than spend further time unpacking these concepts, this paper aims only to demonstrate that different groups of actors involved in trade negotiations over internet public policy issues contest the appropriate meanings of these terms, and to suggest some measures that could be taken to address this contestation, without presupposing exactly where the appropriate balance will ultimately be struck.

\section{TRADE AND INTERNET GOVERNANCE REGIMES}

Trade policymaking was never the province of a single stakeholder group alone. Indeed, in 
medieval times, the "law merchant" or lex mercatoria was a system of non-state transnational law developed principally by merchants themselves, which operated in parallel to the domestic legal regimes of the kingdoms between which they plied their trade (Cutler, 2003, pp. 108-140). This overlapping system of private and public governance effectively wove together the law merchant with the laws of the various sovereign kingdoms into the patchwork quilt that was the earliest form of international trade law regime.

This developed, centuries later, into a more formalised system of international trade law, through the formation of the earliest bilateral trade agreements between nation states, such as the 1860 Cobden-Chevalier Treaty between the United Kingdom and France, and ultimately plurilateral agreements such as the original 1947 General Agreement on Tariffs and Trade (GATT) and its 1994 successor that is now embodied in the World Trade Organisation (WTO) (Hoekman, 2009, 25, p. 47).

But in the meantime, merchants and states were joined by a third stakeholder group seeking its own right of involvement in trade policymaking: civil society. This memorably came to a head in 1999 when anti-WTO protests by civil society groups spilled over onto the streets of Seattle, sending a sharp notice to the organisation that greater inclusiveness, accountability and transparency would henceforth be demanded of the international trade policymaking regime. In the wake of these protests, the WTO began to acknowledge the need for change, with even the former Chairman of the WTO Appellate Body, Ambassador Julian Lacarte (2004), acknowledging that the integration of civil society into the WTO's processes would enhance the organisation's legitimacy by reducing its institutional democratic deficits, and would have capacity building benefits. Eventually some reforms were indeed initiated by the WTO, although compared with most of the bodies of the United Nations (UN) system, it remains much less open to civil society participation (Steffek and Kissling, 2006; Wolfe, 2012).

In parallel to these developments, civil society was forging a very different dynamic with the emerging institutions of governance of the internet. Unlike in the trade regime, academic and civil society participation in the development of the internet's technical infrastructure had been integral from its earliest beginnings (Leiner et al., 2003). Despite the fact that much of the early internet was developed under US government contract, some of its early pioneers were positively hostile to the idea of governments claiming sovereignty over this new realm that nongovernmental stakeholders had built. Drawing on and in turn influencing a canon of "cyberlibertarian" writings in Wired Magazine (Katz, 1997) and American legal journals (Johnson and Post, 1996), the classic expression of this came from the co-founder of my organisation, the Electronic Frontier Foundation (EFF), John Perry Barlow, who wrote in his Declaration of the Independence of Cyberspace:

Governments of the Industrial World, you weary giants of flesh and steel, I come from Cyberspace, the new home of Mind. On behalf of the future, I ask you of the past to leave us alone. You are not welcome among us. You have no sovereignty where we gather. $[\ldots]$

Where there are real conflicts, where there are wrongs, we will identify them and address them by our means. We are forming our own Social Contract. This governance will arise according to the conditions of our world, not yours. (Barlow, 1996) 
Interestingly, such claims did not go entirely unrecognised by governments. In 2003, the United Nations convened the World Summit on the Information Society (WSIS) partly in recognition that "the Information Society is intrinsically global in nature and national efforts need to be supported by effective international and regional cooperation among governments, the private sector, civil society and other stakeholders" (WSIS, 2003, paragraph 60). A final outcome document of this conference, the Tunis Agenda for the Information Society, recognised the need to establish "a transparent, democratic, and multilateral process, with the participation of governments, private sector, civil society and international organisations, in their respective roles" to address the "many cross-cutting international public policy issues that require attention and are not adequately addressed by the current mechanisms" (WSIS, 2005, paras 60$61)$.

While useful, this does not go as far as providing a template for how this proposed model of multi-stakeholder cooperation should be put into practice. After all, internet governance is not a unitary construct, but rather a basket of loosely connected issue areas, each of which are typically governed by a different patchwork-or to shift analogies, a different network-of public and private governance mechanisms (Malcolm 2008, ch. 2). In some of these issue areas, such as the technical administration of the internet, stakeholders participate on an equal footing; a precept derived from the Tunis Agenda, which in turn recognised the central role that civil society had played in the development of the internet (Doria, 2014). This ideal is most closely realised in multi-stakeholder internet governance organisations such as the Internet Corporation for Assigned Names and Numbers (ICANN), the IETF, and the IGF. For example, ICANN, which is responsible for the administration of internet domain names, is led by nongovernmental stakeholders within a multi-stakeholder network that relegates governments to an advisory role. 1

But in other internet governance issue areas, such as cybersecurity, the role of governments has historically been much more central, and more government-centric structures consequently prevail. This also applies to the institutions of the global trading system, which are for the most part intergovernmental in origin and membership (the World Economic Forum, for which the World Social Forum was oppositionally named, is a notable exception), and tend to be inscrutable, closed and opaque in their dealings with the public. Far from offering CSOs the ability to participate on an equal footing as in ICANN, such organisations are lucky if they are even able to read official documents, and perhaps to observe certain meetings (such as the WTO Ministerial Conferences). Indeed, in recent bilateral and plurilateral negotiations such as those over the TPP, TISA, and RCEP, they can expect much less than this (Malcolm, 2010).

These existing institutional power structures are just one of the bases upon which different measures of inclusiveness, accountability and transparency may be appropriate for different issue areas that make up the internet governance regime. The need for differential application of these criteria is reflected in the 2014 NETmundial Multistakeholder Statement, in some ways an update, and in others a challenge to the Tunis Agenda (Maciel, 2014), which recognised that "roles and responsibilities of stakeholders should be interpreted in a flexible manner with reference to the issue under discussion" (NETmundial Multistakeholder Statement, 2014, p. 6).

But this still begs the question, how should stakeholder participation differ from one issue to another? Without attempting to definitively answer that question, this paper endeavours at least to sketch out some of the different positions on this question, as held by trade officials, civil society, not to mention different civil society factions. The paper closes with a description of some projects that could help to bring these parties closer to a common understanding. 


\section{CONTESTED MEANINGS OF INCLUSIVENESS, ACCOUNTABILITY, AND TRANSPARENCY}

\subsection{BETWEEN TRADE OFFICIALS AND CIVIL SOCIETY}

Civil society groups have taken up the challenge of defining what particular measures of inclusiveness, accountability and transparency ought to be demanded of trade policymakers who address internet-related public policy issues, drawing in part on the norms established at WSIS and NETmundial and in other international instruments. The most notable normative document of such demands, at least on a global level, is the 2016 Brussels Declaration on Trade and the Internet, which provides in part:
Any international rulemaking process that affects the online and digital environment should adhere to human rights and good governance obligations to actively disseminate information, promote public participation and provide access to justice in governmental decision-making.

The Declaration goes on to suggest several particular measures that countries could take to this end, including ensuring the pro-active dissemination of information through the release of draft proposals and consolidated texts, providing opportunities for meaningful involvement by civil society representatives such as through public notice and comment and public hearing processes, and requiring balanced representation on any trade advisory bodies.

Since trade is a domain in which government leadership has historically been strongest, trade ministries and negotiators have often resisted these and similar demands or dismissed them outright (Malcolm, 2015b), often while claiming to uphold those very same values. An outline of the contours of inclusiveness, accountability and transparency as these values are defined by trade ministries can be gleaned from comparing the public statements and policies of one such ministry, the Office of the United States Trade Representative (USTR), to civil society demands for improvement of each of these criteria.

On inclusiveness, which in terms of WSIS and NETmundial is about each stakeholder group having an appropriate role in the process, trade negotiators seem to regard this as being largely satisfied by the inclusion of those who are participants in trade, rather than the inclusion of other interest groups that are impacted by trade rules.2 Membership of the US Industry Trade Advisory Committees (ITAC) are therefore heavily dominated by industry. In particular ITAC 8 on Information and Communications Technologies, Services, and Electronic Commerce is exclusively composed of representatives of companies and industry associations. A 2014 USTR call for members of a new Public Interest Trade Advisory Committee was shelved after a year, partly because strict confidentiality rules would have precluded the participation of most CSOs (Anonymous, 2015).

As to accountability, the U.S. Congress is required to approve the USTR's negotiating objectives and its final text, but has only minimal oversight of the negotiations in progress, due to the tightly constrained conditions of access to the negotiating text, as described below. In 2015, the USTR appointed its own General Counsel to the newly-created position of Transparency Officer, putting the incumbent in the invidious position of being expected to defend the office's current practices around transparency, at the same time as reforming those practices. Expressing their 
unease at the lack of external accountability inherent in this arrangement, civil society groups including EFF, the Sunlight Foundation, and OpenTheGovernment.org responded by demanding that the position be made independent of the office (Malcolm, 2017). Beyond this, the only other mechanism of external accountability accepted by the USTR has been the notification of its preferential trade agreements to the WTO.

As to transparency, the United States Trade Representative (USTR) infamously touted the TPP as "the most transparent trade negotiation in history" (Johnson, 2013), despite the fact that no drafts of the agreement were officially released and that the few corporate advisors to the USTR who had access to the text did so under non-disclosure agreement. Although reforms under the Bipartisan Congressional Trade Priorities and Accountability Act of 2015 will give Members of Congress greater access to texts under negotiation, which has been notoriously difficult in the past (Carter, 2012), these reforms do nothing to provide such access to the general public. As might be supposed, this is starkly at odds with civil society's conception of what would amount to adequate transparency.

\subsection{WITHIN CIVIL SOCIETY}

Perhaps surprisingly, disagreements as to the appropriate meanings of inclusiveness, accountability, and transparency in trade policymaking also exist within civil society. However, before explaining these differences, some further background is needed. Despite some overlap, the groups that typically identify as civil society in internet governance discourse are different from those who typically engage in trade policy debates. This is not to suggest that there are only two factions of civil society organisations (CSOs) in the trade and internet regimes, nor that the division between them is always clear. However it is useful for present purposes to distinguish between what we will call the internet CSOs on the one hand, and the trade and development CSOs on the other, to explain some of the observed differences between their policy positions and working styles in trade and internet policy advocacy.

Although both groups engage in rights discourse, one of the most striking differences between them is the focus of the former on individual civil and political rights, whereas the latter is more likely to prioritise collective economic and social rights. Examples of networks of CSOs involved in internet governance include the Non-Commercial Stakeholders Group (NCSG) of ICANN, Best Bits, the Civil Society Internet Governance Caucus (IGC), and the Association for Progressive Communications (APC)..3 Although some of these groups (most notably the last) also advocate for social programmes to bridge the digital divide, they are more often found advancing principles and policies that support users' individual rights to freedom of expression, privacy, and freedom of association. For example, 30 civil society participants in the Best Bits network made a remarkable 34 references to human rights in their 16 paragraph joint submission to the Global Multistakeholder Meeting on the Future of Internet Governance that produced the NETmundial Multistakeholder Statement (Best Bits, 2014).

Remembering that many of these groups draw their lineage, and in many cases their members, from amongst the ranks of internet's early cyber-libertarian pioneers, this individualist orientation should not be surprising. Kelty (2005, pp. 204-205) identifies a "recursive public" of self-identified geeks from which such groups are drawn, who advocate "not just the rhetoric of openness but also a particular attitude toward the conditions of possibility of openness", and who elevate the computer code that defines the network itself over state ordering as a means to realise this ideal. Some such groups at the domestic level, such as TechFreedom (US) maintain an explicitly conservative agenda today, while others such as EFF claim an apolitical or nonpartisan mission, while still pursuing an agenda that emphasises individual rather than 
collective rights. Many of these groups accept corporate donations, and some also solicit grants from OECD governments such as the United States and Sweden.

This contrasts with similar loose groupings of CSOs involved in global debates on trade and development, such as the World Social Forum, and at a domestic US level, the Occupy movement, both of which adopt a strong position of opposition to what is characterised as the hegemonic neoliberal globalisation that underpins the global trading system (Conway, 2013, ch. 3). Trade unions are dominant participants in these civil society movements, and with their very different history of struggle against capitalist oppression, it is in turn no wonder that these civil society networks are much more leftist in orientation, and give far greater emphasis to collective rights. Even at the more "conservative" fringes of this movement, amongst individual NGOs that seek to engage directly with trade policymaking bodies rather than disrupting or overthrowing those bodies, groups such as Public Citizen (US) and Third World Network (Malaysia/Geneva) still maintain strong ties with organised labour, and refuse to accept funds from corporations or governments.

Given this disjunct, at the intersection of these two groupings of internet and trade civil society activists some very interesting tensions naturally emerge. Examples of civil society groups that intersect to a greater or lesser degree between the trade and the internet governance realms include the Civil Society Information Society Advisory Council (CSISAC) of the Organisation for Economic Cooperation and Development (OECD), the Trans-Atlantic Consumer Dialog (TACD), the Open Digital Trade Network, the Just Net Coalition (JNC), and the IGF's Dynamic Coalition on Trade and the Internet.

These differences are most pronounced where they concern substantive digital trade issues, such as network neutrality 4 and data localisation.5 For example, a joint letter of mostly trade and development CSOs released in October 2017 addressing the prospect of data localisation rules being included in the WTO's digital trade agenda states:

\section{What e-commerce proposal proponents call "localization barriers" are actually the tools that countries use to ensure that they can benefit from the presence of transnational corporations to advance their own development and the economic, social, and political rights of their citizens.6}

In contrast, on the same topic the internet-focused EFF warns that "Pushing localization for short-term social, political and economic gains could ultimately harm users and innovators" (Panday, 2017).

The two factions also conceptualise the procedural issues of governance in a trade policymaking context somewhat differently. To repeat the exercise that was undertaken above when comparing the meanings respectively ascribed to the above three attributes of trade policy development processes by trade ministries and civil society, examples of internal disagreements within civil society on these attributes provide an idea of the main divergences between the two civil society factions on inclusiveness, accountability and transparency.

As regards inclusiveness, the biggest disagreements are on the appropriate role of states within multi-stakeholder processes. The trade and development focused CSOs unambiguously consider ICANN-level "equal footing" multi-stakeholder inclusiveness to be a bridge too far, recognising the power differentials between stakeholders that can result in the capture of such processes. A 
typical expression of this is in the founding document of the JNC, the Delhi Declaration (Just Net Coalition, 2014), which states:

\section{The right to make Internet-related public policies lies exclusively with those who legitimately and directly represent people. While there is a pressing need to deepen democracy through innovative methods of participatory democracy, these cannot include-in the name of multi-stakeholderism-new forms of formal political power for corporate interests.}

By contrast, the mainstream internet CSOs, as explained above, tend to support a model of multi-stakeholder governance that does not privilege governments over other stakeholder groups; or at least not as uniformly as the Delhi Declaration suggests. Disagreements on this point have dogged the IGC, Best Bits, and CSISAC.7

Differences on accountability between the two groups are less pronounced, but where they exist they tend to stem from heightened fears by the trade and development CSOs of corporate or governmental capture of a supposedly neutral process. For example, a schism formed between the two civil society factions within the Best Bits civil society network, resulting in the splitting of the JNC as a new network for CSOs from the trade and development camp. A catalyst of this schism was the revelation that a Best Bits member organisation had accepted programme funding from the U.S. State Department, which that member had in turn used to fund its contribution to a Best Bits meeting. Although regarded as a unexceptional internal matter by many of the mainstream internet CSOs, for those who split off into JNC, the CSO's failure to disclose that funding link amounted to a serious breach of accountability norms that threw the legitimacy of the entire network into question.

On transparency, the trade and development CSOs are more strategic about accepting certain closed processes than the internet-focused CSOs tend to be. For example, it is common practice for internet governance institutions to operate open mailing lists with public archives, to maintain documentation in open wikis, and in some cases (for example, at ICANN) also to record and transcribe meetings. While CSOs that are primarily involved in internet governance tend to apply these same standards to their own internal groups, lists, and documentation, this is quite foreign to the groups that are involved in trade advocacy. The latter tend to operate gated or invitation-only lists and meetings, without publicly available records of discussions or work product. Indeed, it is common for activists to be subdivided into an outer and an inner circle, with only the inner circle having access to a "core list" on which only the most sensitive information is exchanged. This has become a bone of contention when groups from each of the two civil society camps come together, as in the cases of the IGC, Best Bits, and the Open Digital Trade Network.

To some extent, the differing expectations of these civil society factions around inclusiveness, accountability, and transparency are shaped by realpolitik. Since stakeholders in the internet governance regime commence from a position of relative inclusion and transparency, it is natural for them to expect this to be extended to trade fora that overlap with internet governance. Since the trade policymaking community doesn't bestow any such privileges on civil society stakeholders, they are less accustomed to the same, even when the issues being discussed in trade fora turn from traditional trade topics to digital trade rules that have historically been discussed more openly and inclusively by other institutions. 
However, this doesn't fully explain the differences between the two factions. It is posited that at a deeper level there is also an underlying ideological distinction between the two civil society factions-that mainstream CSOs engaged in internet policy discussions tend to be more libertarian (at least as concerns internet public policy development) and to frame their demands in terms of civil rights, whereas the mainstream CSOs inhabiting the trade policymaking regime are generally more collectivist and more likely to frame their concerns in terms of global and social justice. This results in the trade and development NGOs being more cautious about corporate capture in the meanings that they ascribe to inclusiveness, accountability, and transparency in trade policy development. It is important that these differences be acknowledged in developing mechanisms to help resolve these contested meanings.

\section{RECONCILING THESE CONTESTED MEANINGS}

In summary then, the important differences of meaning ascribed to the criterion of inclusiveness turn on whether and which non-governmental stakeholders are to be included. For both trade ministries and CSOs there is a consensus that non-governmental stakeholders should be consulted in trade policy development, but internet-focused NGOs are more likely to go further and demand a deeper level of multi-stakeholder involvement that is troubling to CSOs from the trade and development space. As to which non-governmental stakeholders should be involved, trade ministries tend to be most supportive of the inclusion of corporations (since they are actually involved in trade), trade CSOs tend to be least supportive of this due to their fears that corporations will capture the process, and internet CSOs are more likely to support the involvement of all affected non-governmental stakeholders on an equal footing, as this is a precept of multi-stakeholderism in the internet governance regime.

Summarising the differences that exist on the meaning ascribed to the accountability of trade policy development processes, it can be observed that trade ministries do not interpret this as requiring close oversight from the legislative branch or from any other external authority (other than the notification of preferential trade agreements to the WTO). Both the trade and internet focused CSOs are unified in their expectation of closer public oversight of the process. To the extent that there is a difference between the two factions of CSOs, it relates to the accountability of non-governmental stakeholders. Pointing to examples in which they see multi-stakeholder processes as having been captured by corporate interests (Moog, Spicer and Böhm, 2015), the trade CSOs are likely to be far less comfortable with the increased involvement of nongovernmental stakeholders in trade policy development unless adequate accountability mechanisms, including mechanisms of financial accountability, are first established.

Finally to summarise the main differences of expectations around the transparency of trade policy development processes, the biggest contestation that can be observed is between the trade ministries, who regard their current transparency practices as adequate, and the CSOs, who are demanding deep reforms such as the publication of proposals and drafts. As between the two factions of CSOs, there is a smaller divergence between the internet-focused CSOs who are more likely to expect a more radical degree of transparency aligned with the practices of internet governance institutions, and the trade CSOs, who seem to be more accepting of a lesser level of transparency, for example excluding measures such as the publication of correspondence and meeting transcript.

On each of these measures, can a middle ground be reached that both acknowledges the political realities within which the trade negotiators work, while also satisfying the shared expectations 
of enhanced inclusiveness, accountability, and transparency from both of the civil society factions that engage in trade policy advocacy? If so, the first step is to identify the contested meanings of these concepts, and to provide fora in which these differences can be explained, discussed, and ultimately reconciled. Towards this end, three related projects led by the author at EFF are now presented.

\subsection{OPEN DIGITAL TRADE NETWORK}

The first of these is the Open Digital Trade Network, which was formed in February 2016 out of the group that had met the previous month in Brussels to produce the Brussels Declaration on Trade and the Internet. EFF selected the approximately 30 participants at the meeting based on personal contacts and recommendations, to include a cross-section of those who had knowledge of the global trading system, and those with expertise in internet governance. Although most participants were from civil society, the group was rounded out with the participation of a small number of private sector participants who were known to be receptive to the reform of trade negotiation processes, as well as one participant associated with the United Nations.

The diversity of the group helped to ensure that its recommendations were balanced. For example, the group concluded that "There is a spectrum of public participation in policy institutions, and the politics of trade negotiations constrain our ability to be empowered directly at the highest levels", an insight that might have been lost if the group had excluded trade CSOs; but conversely, the group also agreed on "drafting of model texts that draw on established human rights, Internet governance and development norms", which would not have been recognised if internet CSOs had been absent.

Considerations of the cultural and ideological differences between civil society factions shaped the work of the Open Digital Trade Network in several ways. The group employed a deliberative democratic methodology, designed to reduce the possibility of domination by any single group. This included the co-development of a balanced background briefing paper, the use of "Idea Rating Sheets" for brainstorming and gaining peer feedback on ideas, and actively facilitated small group discussion.

Knowing of the reticence of trade CSOs to the radical transparency common in internet governance spaces, the group's Brussels meeting was conducted under Chatham House rules, and the subsequently-formed mailing list and web platform were made accessible to members only. Those who applied for membership of the group following its formation could only do so upon the recommendation of an existing member, which also differs from the typical practice of internet governance community groups such as Best Bits, which tend to be more overtly open.

But not all of the cultural differences of CSO participants were as successfully managed. In particular, the deeper differences of opinion on substantive internet policy issues resulted in some heated exchanges, and ultimately resulted in the group mutually deciding to refocus on procedural questions only. Even on such matters of process, there were also disagreements between the two CSO factions. For example, objections were raised to the participation of private sector members in the group, and one of the trade-focused CSO representatives also expressed concern about other members of the network having received grant funding from Google.8

Today, the Open Digital Trade Network continues to operate as a distributed online network of about 60 experts, lobbyists, and activists, based around a mailing list and a web platform that provides a project management system and knowledge base. With EFF's continued loose coordination, members of the network collaborate on specific projects of mutual interest such as 
workshops, meetings with trade negotiators, drafting and delivery of joint statements, and the exchange of information on negotiations in progress.

\subsection{IGF DYNAMIC COALITION ON TRADE AND THE INTERNET}

The Internet Governance Forum's Dynamic Coalition on Trade and the Internet was established in February 2017 to extend the mission of the Open Digital Trade Network to a broader group of stakeholders, including additional industry participants and, it was hoped, government representatives such as trade policymakers. Through the common management of both projects by EFF, the Dynamic Coalition maintains a close relationship with the Open Digital Trade Network and aims to build upon rather than to duplicate its work. Amongst the items contained in the Dynamic Coalition's 2017 action plan are to develop a multi-stakeholder approach to facilitating the transparency and inclusiveness in international trade negotiations and domestic consultation processes, and to build a network of representatives from trade institutions and delegations for liaison with the Dynamic Coalition and the broader IGF community.

The even more diverse membership of the Dynamic Coalition makes the coalition potentially better equipped to develop a broadly acceptable resolution of the contested meanings of the inclusiveness, accountability and transparency of trade policymaking processes, and to disseminate that learning to affected stakeholders. On the other hand, the very diversity of a multi-stakeholder group also makes it more difficult for it to arrive at a meaningful consensus, and amplifies the accountability fears of trade and development CSOs, who fear that the prospect of the group's capture by narrow corporate interests.

The IGF addresses concerns about accountability and transparency of its Dynamic Coalitions by requiring them to comply with three basic principles of inclusiveness and transparency for carrying out their work: open membership, open mailing lists, and open archives. They must also ensure their statements and outputs reflect minority or dissenting viewpoints. These requirements, perhaps naturally, more closely resemble those of working groups associated with other internet governance institutions than those associated with the trade policy regime.

Although this sets a positive precedent for a group concerned with advocating for inclusiveness and transparency in trade policy development, on a practical level it also seems to have operated against the Dynamic Coalition. The limited participation that the group has enjoyed since its formation suggests that some members are reticent to participate openly, as they have not established mutual trust and may fear (legitimately, based on the experiences of similar groups) that fellow members might not participate in good faith. The group's diversity also calls into question whether it will be capable of reaching a consensus position on the reform of trade negotiation processes that would be at a similar level of ambition to those reached by the Open Digital Trade Network. It remains to be seen whether the Dynamic Coalition will live up to the potential envisioned for it by EFF.

The Dynamic Coalition had 42 members at the time of its inaugural meeting in December 2017 at the 2017 IGF meeting in Geneva. At that meeting, a joint statement on transparency in trade negotiations was endorsed by consensus, and participants agreed to embark on a process of outreach to additional stakeholders from governments, the Internet business community, and trade organizations such as UNCTAD and the WTO. The success of that endeavour could be expected to positively affect the group's standing and influence, but perhaps also to increase the difficulty of it reaching consensus on future resolutions such as its statement on transparency. 


\subsection{SHADOW REGULATION}

Each of the preceding projects is aimed at bringing together specific participants from the trade and internet governance regimes, as it is they who are most closely connected with the institutions that can effect the desired improvements to the inclusiveness, accountability and transparency of trade negotiation processes. The Shadow Regulation project is different in that it is intended to help raise awareness of the need for such reforms within a broader public sphere. Neither is it specifically restricted to recommending improvements in these practices within trade negotiations alone. Instead the recommendations are generalised to be capable of application to any body engaged in transnational public policy development.

The process recommendations that form part of the Shadow Regulation project have been distilled into the simplified form of three criteria which are captured on an infographic specifically designed to aid its dissemination to a broad public involved in a diverse range of public policy development processes. The criteria provide:

- Inclusion: We need to make sure that all stakeholders who are affected by internet policies have not only the opportunity, but also the resources, to be heard.

- Balance: Reaching the optimal solution requires letting the best ideas rise to the top, even if governments and corporations don't always get their way.

- Accountability: Institutions and stakeholders who participate in crafting rules, standards or principles for the internet must be transparent and deserving of our trust.

Despite the differences between the Shadow Regulation project and the preceding projects, it was developed with similar attention to the need for its principles to address the needs of the diverse institutions and CSO communities whose buy-in would be essential for their wide acceptance. For example, one concern common to both civil society factions, but expressed most strongly by those from the trade and development camp, is that multi-stakeholder processes are vulnerable to capture by corporations (Moog, Spicer, \& Böhm, 2015).

For corporations, multi-stakeholder processes may offer an attractive opportunity to stave off pressure for hard regulation by governments, along with the perception of greater legitimacy than pure self-regulation. Thus, although originally opposed to the formation of the IGF, private sector actors soon metamorphosed into its strong supporters (Malcolm, 2008, p. 350). But the greater resources that corporate actors can draw upon in multi-stakeholder discussions, relative to those of civil society, also create clear risks that they will dominate processes that are not adequately managed to prevent this (Conger, 2017).

The paper of the author that formed the basis for the principles (Malcolm, 2015a) takes particular care to address these concerns, acknowledging that:

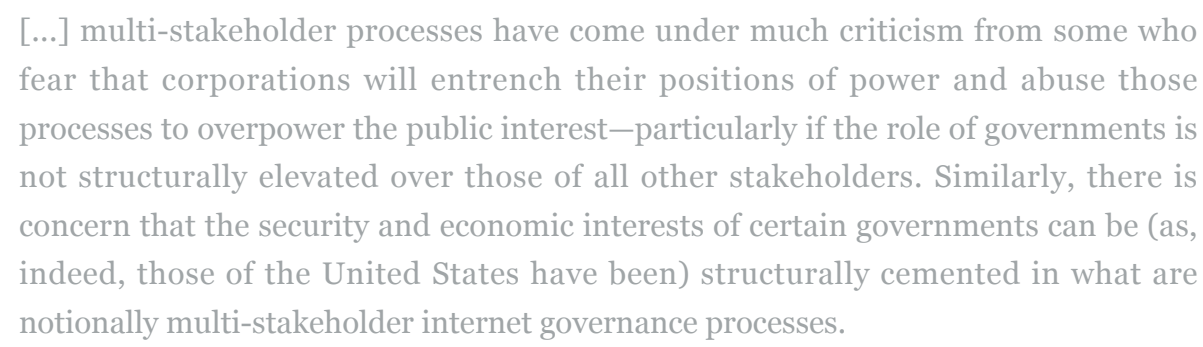

Despite careful crafting of this project to present process criteria capable of broad adoption, by its nature the success of this project is less susceptible to evaluation. It seems unlikely that the 
minimal resources that $\mathrm{EFF}$ alone can devote to dissemination of the principles will enable it to produce a measurable impact on improving the receptiveness of policymakers to embracing inclusiveness, accountability or transparency reforms. The further success of this project depends upon the term "Shadow Regulation" catching on and self-replicating, meme-like, in the consciousness of internet users and policymakers.

Unlike the other projects mentioned, Shadow Regulation is not a membership-based group, but an endeavour to attach an easily understood viral brand to the process norms that underpin our trade reform advocacy as well as our critiques of other closed and opaque policy processes. As such, Shadow Regulation provides a resource designed to be suitable for diverse civil society groups to draw upon to support their advocacy work.

\section{CONCLUSION}

In promoting the improvement of the inclusiveness, accountability and transparency of trade policymaking processes, it might be assumed that all of the parties begin with a common understanding of what those criteria mean, and simply differ on the desirability of implementing them. This paper has demonstrated why that is not the case, and why there may actually be misunderstandings not only between trade ministries and civil society, but even within civil society, about what inclusiveness, accountability or transparency mean in the context of public policy development. To some extent, the different meanings attached to these criteria stem from the differences in the institutional development of the internet governance and the trade policymaking regimes, which in turn have influenced the expectations of the institutions and CSOs respectively engaged in each of those areas.

But underlying this is a deeper explanation. Mainstream CSOs that focus on internet activism tend to favour governance mechanisms based on markets, technology, and decentralised collective action, rather than intervention by government. Even when government intervention is recommended, this is often limited to upholding individual rights, rather than the provision of broad or intrusive social programmes that would significantly affect the administration or operation of the network. This resembles a skew to the right, at least in respect of internet policy issues. In contrast, mainstream CSOs that focus on trade and development are much more likely to exhibit a skew to the political left, and to favour government intervention to address problems at the intersection of technology policy and trade, even where such intervention would have redistributive effects, or would place new restrictions on the free flow of data across the internet-a shibboleth to mainstream internet-focused CSOs.

These divergences not only affect the respective positions of the two factions of CSOs on substantive internet and trade policy issues, but also their attitudes towards the processes by which internet-related trade rules are developed, including how the inclusiveness of such processes should be assessed, what measures of accountability are important, and how transparency is to be operationalised. This rift assumes importance because of the increasing convergence of these two very different regimes of internet governance and trade, which increasingly finds institutions and the CSOs who participate in them being required to cooperate. Unless a project is undertaken to reconcile the contested meanings of inclusiveness, accountability and transparency held by civil society stakeholders and the institutions in which they work, then the result is misunderstanding at best, and conflict at worst.

This paper does not suggest exactly where that balance should be struck, for example, what 
accountability measures should be required of non-governmental stakeholders, or whether meetings of trade negotiators should be open to public interest representatives. These are important questions, but beyond the scope of the paper. Rather, it suggests that we must acknowledge the contested meanings of inclusiveness, accountability and transparency in the context of trade policymaking and work towards their reconciliation, before we can expect to arrive at mutually acceptable improvements to trade policymaking processes.

Three related projects of EFF have been put forward in response to this challenge. The Open Digital Trade Network was formed in an effort to create a coalition of activists and policy experts at the intersection of the two domains, who despite their diverse positions on substantive internet policy issues, could agree on reforms to trade negotiation processes that would bring them in line with norms of transparency and public participation drawn in part from the internet governance regime.

The IGF Dynamic Coalition on Trade and the Internet was an extension of the Open Digital Trade Network aimed at extending the consensus on these recommendations for reform to a broader set of stakeholders, who through their connections with a diversity of policymaking fora, could begin to disseminate these recommendations as best practices. Finally EFF's Shadow Regulation project, aimed at a still broader community of interest, utilises an infographic to disseminate a simple lexicon of process criteria that can be promulgated as a best practice standard for the development of cross-border internet-related public policies, whether traderelated or otherwise.

But of course, more is required to complete the broader enterprise of which these ongoing projects form part. For example, a research project identified early on by the Open Digital Trade Network, but not yet undertaken, is defining more precisely the levels of multi-stakeholder participation and transparency that could be appropriate at different points in internet public policy development through trade negotiations, and on different policy issues. It is here where the differences between civil society factions may assume as much importance as the divergences between CSOs and trade ministries.

This paper has highlighted the need for those engaged in such future exercises to remain cognisant of the realpolitik of the trade negotiator, and of the political ideologies and concerns of each civil society faction, such as those around corporate capture of multi-stakeholder processes and their potential to usurp the legitimate authority of states. After all, the reform of trade negotiation practices will only be accomplished to the extent that it is broadly supported, which in turn requires reform proposals to be compatible with the needs and values of all involved stakeholders. 


\section{REFERENCES}

Anonymous. (2015). A year after unveiling, "PITAC" stalled due to fight over secrecy rules. Inside U.S. Trade, 27 Feb.

Barlow, J. P. (1996). A declaration of the independence of cyberspace. Retrieved from https://www.eff.org/cyberspace-independence

Belli, L. (2015). A heterostakeholder cooperation for sustainable internet policymaking. Internet Policy Review, 4(2). doi:10.14763/2015.2.364

Best Bits. (2014, March). Internet governance principles and human rights. Retrieved from http://content.netmundial.br/contribution/internet-governance-principles-and-human-rights/ 107

Brussels Declaration on Trade and the Internet. (2016, February). Retrieved from https://www.eff.org/files/2016/o3/15/brussels_declaration.pdf

Carter, Z. (2012). Trans-Pacific Partnership: key senate Democrat joins bipartisan trade revolt against Obama. Huffington Post, 23 May. Retrieved from

http://www.huffingtonpost.com/2012/o5/23/trans-pacific-partnership-ron-wyden_n_154098 4.html

Conway, J. (2013). Edges of global justice: the world social forum and its "others". Rethinking glob- alizations. Routledge. Retrieved from

https://books.google.com/books?id=yqyVnwVv5hEC

Conger, K. (2017). The fight over DRM standards for streaming video is over and big business won. Gizmodo, 18 September. Retrieved from https://gizmodo.com/the-fight-over-drmstandards-for-streaming-video-is-ove-1818520581.

Cutler, A. C. (2003). Private power and global authority: transnational merchant law in the global political economy. Cambridge: Cambridge University Press.

Doria, A. (2014). Use [and Abuse] of Multistakeholderism in the Internet. In R. Radu, R. H. Weber, \& J.-M. Chenou (Eds.), The evolution of global internet governance: principles and policies in the making (pp. 115-140). Berlin, Heidelberg: Springer.

Futter, A., \& Gillwald, A. (2015). Zero-rated internet services: What is to be done? (Policy Paper No. 1, 2015). Research ICT Africa. Retrieved from

https://www.researchictafrica.net/docs/Facebook\%20zerorating\%2oFinal_Web.pdf

Hoekman, B. M. (2009). The political economy of the world trading system (3rd ed.). Oxford: Oxford University Press.

Katz, J. (1997). Birth of a digital nation. Wired Magazine, 5.

James, D. (2017). Twelve reasons to oppose rules on digital commerce in the WTO. Huffington Post, 12 May 2017. Retrieved from

http://www.huffingtonpost.com/entry/5915db61e4bobd9of8e6a48a

Johnson, D. R., \& Post, D. (1996). Law and Borders: The Rise of Law in Cyberspace. Stanford Law Review, 48(5), 1367. doi:10.2307/1229390 
Johnson, T. (2013). U.S. trade representative defends pending trade pact after Wikileaks disclosure. Variety, November 13. Retrieved from https://variety.com/2013/biz/news/u-strade-representative-says-pending-pact-has-zero-to-do-with-sopa-120083886o/

Just Net Coalition. (2014, February). The Delhi declaration for a just and equitable internet. Retrieved from https://justnetcoalition.org/delhi-declaration

Kelty, C. (2005). Geeks, social imaginaries, and recursive publics. Cultural Anthropology, 20(2), 185-214. doi:10.1525/can.2005.20.2.185

Lacarte, J. A. (2004). Transparency, public debate and participation by NGOs in the WTO: A WTO perspective. Journal of International Economic Law, 7(3), 683-686.

doi:10.1093/jiel/7.3.683

Leiner, B. M., Cerf, V. G., Clark, D. D., Kahn, R. E., Kleinrock, L., Lynch, D. C., ... Wol , S. (2003). A brief history of the internet. Retrieved from

http://www.isoc.org/internet/history/brief.shtml

Maciel, M. (2014). Creating a Global Internet Public Policy Space: Is There a Way Forward? In W. J. Drake \& M. Price (Eds.), Beyond Netmundial: The Roadmap for Institutional Improvements to the Global Internet Governance Ecosystem (pp. 99-107). Philadelphia: Internet Policy Observatory. Retrieved from https://repository.upenn.edu/internetpolicyobservatory/5

Malcolm, J. (2008). Multi-Stakeholder Governance and the Internet Governance Forum. Perth: Terminus Press.

Malcolm, J. (2010). Public Interest Representation in Global IP Policy Institutions. Retrieved from https://digitalcommons.wcl.american.edu/research/6/.

Malcolm, J. (2015a). Criteria of meaningful stakeholder inclusion in internet governance. Internet Policy Review, 4(4). Retrieved from https://policyreview.info/articles/analysis/criteria-meaningful-stakeholder-inclusion-internetgovernance doi:10.14763/2015.4.391

Malcolm, J. (2015b, October). U.S. open government commitments fail to improve trade transparency. Retrieved from https://www.eff.org/deeplinks/2015/10/us-open-governmentcommitments-fail-improve-trade-transparency

Malcolm, J. (2017, January). Does Trump's withdrawal from TPP signal a new approach to trade agreements? Retrieved from https://www.eff.org/deeplinks/2017/o1/does-trumpswithdrawal-tpp-signal-new-approach-trade-agreements

Mena, S., \& Palazzo, G. (2012). Input and Output Legitimacy of Multi-Stakeholder Initiatives. Business Ethics Quarterly, 22(3), 527-556. doi:10.5840/beq201222333

Moog, S., Spicer, A., \& Böhm, S. (2015). The politics of multi-stakeholder initiatives: The crisis of the Forest Stewardship Council. Journal of Business Ethics, 128(3), 469-493.

doi:10.1007/s10551-013-2033-3

Mueller, M. L. (2010). Networks and states: The global politics of Internet governance. Cambridge, Mass: MIT Press. doi:10.7551/mitpress/9780262014595.001.0001 
NETmundial Multistakeholder Statement. (2014, April). Retrieved from http://netmundial.br/wp-content/uploads/2014/o4/NETmundial-Multistakeholder-Document .pdf

Panday, J. (2017, August). Rising demands for data localization a response to weak data protection mechanisms. Retrieved from https://www.eff.org/deeplinks/2017/o8/risingdemands-data-localization-response-weak-data-protection-mechanisms

Piotrowski, S. J., \& Borry, E. (2010). An analytic framework for open meetings and transparency. Public Administration and Management, 15(1), 138-176.

Steffek, J. \& Kissling, C. (2006). Civil Society Participation in International Governance: the UN and the WTO Compared. Retrieved from

http://econstor.eu/bitstream/10419/24955/1/514659831.pdf

Wolfe, R. (2012). Protectionism and multilateral accountability during the great recession: drawing inferences from dogs not barking. J. World Trade, 46, 777.

WSIS. (2003). Declaration of principles. Retrieved from

http://www.itu.int/wsis/docs/geneva/official/dop.html

WSIS. (2005). Tunis Agenda for the Information Society. Retrieved from

http://www.itu.int/wsis/docs2/tunis/off/6rev1.html

\section{FOOTNOTES}

1. Note that this it not to suggest that the notional "equal footing" of participating stakeholders within ICANN effectively equalises their respective power relations within that organisation; a problem of the multi-stakeholder model to which we will shortly return.

2. This derives from the author's personal observations during discussions with staff of the United States Trade Representatives during negotiations of the TPP and NAFTA during 2016 and 2017.

3. Links to and further information about each of these groups may be found at the website of the Internet Governance Civil Society Coordination Group (CSCG), a peak body that contains representatives of each and functions to "ensure a coordinated civil society response and conduit when it comes to making civil society appointments to outside bodies":

http://internetgov-cs.org/.

4. On network neutrality (the principle that internet providers should not discriminate between data on the basis of type, source, or destination), the mainstream internet civil society position is that such discrimination ought not to be allowed, because it interferes with the user's freedom to access all internet content on a level footing. But civil society groups that are not primarily concerned with internet policy are more inclined to favour such discrimination, through mechanisms such as "zero rating" or differential pricing for certain internet content, in order to facilitate access by marginalised groups (as the US National Association for the Advancement of Colored People (NAACP) contends), or underserved populations in the developing countries of Africa (Futter and Gillwald, 2015).

5. These are domestic laws or policies that mandate or give priority to the use of domestic Internet hosting providers or networks, on which the position generally favored by Internet 
governance civil society groups is that such rules interfere with the free flow of data online, and should be disallowed. However there are developing country groups and networks, such as the South Center and the Our World Is Not For Sale network, that favor certain protectionist measures as a way to give developing country entrepreneurs a leg up over dominant Internet platforms from the developed world (James 2017).

6. The letter, published at https://justnetcoalition.org/2017/to_WTO_Agenda.pdf, is endorsed by 300 groups including numerous trade unions and fair trade groups, but few internet-focused CSOs.

7. The author makes this observation as a participant in each of these organisations, being a member and former coordinator of the IGC, founder and steering committee member of Best Bits, and steering committee member of CSISAC.

8. The author is reporting on discussions to which he was a party as EFF's representative as convener of the Open Digital Trade Network. 